\title{
Uji Antagonis Pseudomonas flourescens spp. Terhadap Isolat Bakteri Xanthomonas (SL3) dari Daun Padi Bergejala Hawar di Kabupaten Kubu Raya
}

\author{
(Antagonist Test of Pseudomonas flourescens spp. on Bacteria Isolates \\ Xanthomonas (SL3) from Rice Leaves Symptomatic of Blight in Kubu Raya District)
}

\author{
Suprih Larasaty ${ }^{1 *}$, Mukarlina ${ }^{1}$, Rikhsan Kurniatuhadi ${ }^{2}$ \\ ${ }^{1)}$ Universitas Tanjungpura; Jl. Prof. Dr. H. Hadari Nawawi, Pontianak, Kalimantan Barat, Indonesia \\ ${ }^{2)}$ Program Studi Biologi, Jurusan Biologi FMIPA Untan Kalimantan Barat 78124 \\ *Email: larasaty104@gmail.com
}

(Article History: Received 21 October 2020; Revised 5 November 2020; Accepted 11 November 2020)

\section{ABSTRAK}

Penyakit hawar pada tanaman padi disebabkan oleh bakteri anggota genus Xanthomonas. Pengendalian penyakit tanaman dapat menggunakan bakteri sebagai Agen Pengendalian Hayati (APH) yang bersifat antagonis terhadap patogen. Pseudomonas flourescens merupakan APH yang memiliki kemampuan penghambatan terhadap bakteri patogen Xanthomonas. P. flourescens spp yang diisolasi dari rhizosfer berbeda memiliki kemampuan penghambatan yang berbeda. Penelitian ini bertujuan untuk menguji kemampuan daya hambat bakteri $P$. flourescens spp. yang berasal dari rhizosfer yang berbeda terhadap bakteri Xanthomonas yang diisolasi dari daun padi bergejala hawar di Kabupaten Kubu Raya. Penelitian ini dilakukan pada bulan Mei 2019 bertempat di Jurusan Biologi Fakultas Matematika dan Ilmu Pengetahuan Alam Universitas Tanjungpura Pontianak. Pengambilan sampel dilakukan di sentra produksi padi Desa Limbung Kabupaten Kubu Raya. Uji antagonis dilakukan di Laboratorium Mikrobiologi Fakultas Matematika dan Ilmu Pengetahuan Alam Universitas Tanjungpura Pontianak menggunakan metode Kirby-bauer. Hasil uji antagonis menunjukkan kedua bakteri $P$. flourescens spp. mampu menghambat isolat bakteri genus Xanthomonas. Jenis $P$. flourescens spp (Sgu5) memiliki kemampuan penghambatan terbaik hingga mencapai 8,43 $\mathrm{mm}$.

Kata kunci: Agen pengendalian hayati; Penyakit Hawar; Pseudomonas flourescens; Xanthomonas (SL3)

\begin{abstract}
Blight disease in rice plants is caused by bacteria belonging to the genus Xanthomonas. Plant disease control can use the Biological Control Agent (APH) which is antagonistic to pathogens.Pseudomonas flourescens is an APH that has the ability to inhibit the pathogenic bacteria Xanthomonas. Pseudomonas flourescens spp. isolated from different rhizosphere had different inhibitory abilities. This study aims to determine the inhibitory ability of the bacteria Pseudomonas flourescens spp. against bacteria isolated from blight with symptomatic rice in Kubu Raya Regency. The research was conducted in my 2019 at the Biology Department, Faculty of Mathematics and Natural Sciences, Tanjungpura University Pontianak. Sampling was carried out at the rice production center in Limbung Village, Kubu Raya Regency.The antagonist test was carried out at the Microbiology Laboratory of the Faculty of Mathematics and Natural Sciences, Tanjungpura University, Pontianak using the Kirby-bauer method. The antagonist test result showed that both Pseudomonas flourescens spp. able to inhibit bacterial isolates of the genus Xanthomonas. Pseudomonas flourescens spp. (Sgu5) has the best inhibition ability up to $8.43 \mathrm{~mm}$.
\end{abstract}

Keywords: Biological control agent; Blight disease; Pseudomonas flourescens; Xanthomonas (SL3)

\section{PENDAHULUAN}

Tanaman padi merupakan tanaman pokok yang dikonsumsi hampir seluruh masyarakat Indonesia. Menurut data dari Badan Pusat Statistik Kabupaten Kubu Raya (2016) luas areal tanaman padi pada tahun 2014 sebesar 59.945 ha dengan produksi padi mencapai 204.350 ton sedangkan pada tahun 2015 produksi padi mengalami penurunan menjadi 180.429 ton dengan luas areal tanam sebesar 52.679 ha. Hal ini menunjukkan produksi padi di Kabupaten Kubu Raya mengalami penurunan hingga $12,33 \%$ seiring dengan menurunnya luas areal tanam.

Terjadinya penurunan produksi padi salah satunya disebabkan oleh penyakit hawar daun 
yang menyerang tanaman padi mulai dari semai hingga menjelang panen. Dampak penyakit ini dapat membuat tanaman tumbuh tidak normal, menurunnya hasil produksi, menurunnya kualitas gabah dan kualitas benih sehingga penyebaran penyakit di lapangan sulit dikendalikan. Pengendalian yang sering digunakan oleh masyarakat adalah menggunakan pestisida sintetik. Penggunaan pestisida sintetik dianggap efektif dalam mengendalikan penyakit hawar daun, namun penggunaannya secara terus menerus dapat memicu terjadinya resistensi patogen sehingga pengendalian selanjutnya sulit untuk dilakukan.

Usaha yang dapat dilakukan untuk mengurangi dampak negatif tersebut adalah mencari teknologi alternatif, salah satunya dengan menggunakan Agen Pengendali Hayati. Penelitian Damanik et al. (2013) mampu menurunkan tingkat serangan penyakit hawar hingga $4,74 \%$ dengan melakukan uji efikasi terhadap agen hayati dengan formulasi antara jamur Trichoderma sp. dan Pseudomonas flourescens. Berdasarkan penelitian Hanudin et al. (2009) bakteri Pseudomonas flourescens yang diisolasi dari tempat berbeda memiliki kemampuan penghambatan yang berbeda-beda. Wibisono et al. (2014) berhasil membuktikan bahwa tujuh strain bakteri Pseudomonas flourescens yang berbeda memiliki kemampuan penghambatan yang berbeda terhadap jamur patogen Rhizoctonia solani. Oleh karena itu, perlu adanya penelitian lebih lanjut terhadap isolat lokal Pseudomonas flourescens spp. yang diisolasi dari rhizosfer yang berbeda yang bertujuan untuk menguji kemampuan daya hambat bakteri $P$. flourescens spp. yang diisolasi dari rhizosfer yang berbeda terhadap bakteri Xanthomonas penyebab penyakit hawar. Mengingat wilayah Kalimantan Barat memiliki kondisi lingkungan yang sebagian besar terdiri dari lahan gambut dan dilalui oleh garis khatulistiwa sehingga dapat menyebabkan perbedaan dalam kemampuan bakteri antagonis. Penelitian ini bertujuan untuk menguji kemampuan daya hambat bakteri Pseudomonas flourescens spp. yang berasal dari rhizosfer yang berbeda terhadap bakteri Xanthomonas yang diisolasi dari daun padi bergejala hawar di Kabupaten Kubu Raya.

\section{METODE}

Survei pengamatan gejala dan pengambilan sampel daun padi dilakukan di sentra produksi padi Kabupaten Kubu Raya dengan cara mencari adanya gejala hawar pada daun tanaman padi yang berada di lokasi tersebut. Sampel daun padi diambil di wilayah Kecamatan Sungai Raya dengan cara menjelajahi sawah yang telah ditentukan berdasarkan survei sebelumnya. Sampel daun yang menunjukkan gejala hawar diambil menggunakan gunting sebanyak 10-20 lembar dan dimasukkan ke dalam kantong plastik steril kemudian dibawa ke laboratorium (Herawati 2016).

Isolasi bakteri dilakukan dengan cara memotong bagian daun yang menunjukkan gejala hawar pada batas bagian tanaman yang sakit dan sehat. Potongan daun tersebut dicuci dengan air steril. Daun kemudian digerus menggunakan mortar hingga halus dan ditambah dengan $1 \mathrm{ml}$ akuades steril. Daun padi yang telah digerus ditimbang sebanyak 1 gram kemudian dimasukkan ke dalam tabung reaksi berisi akuades steril $9 \mathrm{ml}$ untuk diencerkan, kemudian di vortex hingga suspensi homogen (Fitriah et al. 2014). Suspensi bakteri homogen selanjutnya diambil sebanyak $1 \mathrm{ml}$, kemudian diencerkan kedalam tabung reaksi yang berisi 9 $\mathrm{ml}$ akuades steril. Pengenceran dilakukan dengan cara yang sama hingga pengenceran $10^{-4}$. Suspensi bakteri dari masing-masing pengenceran diambil $0,1 \mathrm{ml}$ kemudian ditumbuhkan pada media NA (Nutrient Agar) dan diinkubasi selama 24 jam.

Isolat bakteri yang diperoleh dari hasil isolasi daun tanaman padi yang bergejala penyakit hawar kemudian diremajakan pada media NA. Isolat bakteri patogen yang sudah murni kemudian dibuat suspensi dengan cara mengkultur bakteri patogen pada media cair NB, kemudian diinkubasi pada rotary shaker selama 48 jam pada suhu ruang dengan kecepatan 150 rpm (Manimegalai et al. 2014).

Bakteri Pseudomonas fluorescens yang berasal dari koleksi Laboratorium Balai Proteksi Tanaman Perkebunan (BPTP) Kalimantan Barat diremajakan di media NA dan diinkubasi pada suhu ruang selama 24 jam. Pembuatan suspensi $P$. flourescens yang akan digunakan untuk uji antagonis dibuat dengan cara mengkultur bakteri $P$. flourescens pada media cair NB, kemudian diinkubasi pada rotary shaker selama 72 jam pada suhu ruang dengan kecepatan $150 \mathrm{rpm}$. Suspensi bakteri selanjutnya diencerkan pada akuades steril hingga konsentrasi $1 \times 10^{7-}$ $1 \times 10^{8} \mathrm{CFU} / \mathrm{ml}$ atau setara dengan $1 \mathrm{Mc}$-farland (Sands, 1990; Widodo et al. 2007).

Uji antagonis bakteri Pseudomonas flourescens spp. dilakukan dengan metode 
Kirby-Bauer. Suspensi bakteri patogen yang sudah tersedia selanjutnya ditumbuhkan pada media NA dengan cara diusap. Kertas saring steril berdiameter $5 \mathrm{~mm}$ direndam ke dalam suspensi bakteri antagonis dengan konsentrasi $1 \times 10^{7} \mathrm{CFU} / \mathrm{ml}-1 \times 10^{8} \mathrm{CFU} / \mathrm{ml}$ atau setara dengan 1 Mc-Farland selama 10 menit (Nuria, 2010; Sakinah et al. 2014). Selanjutnya diinokulasikan pada bagian tengah cawan petri yang berjarak 4 $\mathrm{cm}$ dari tepi cawan petri. Bakteri kemudian diinkubasi pada suhu ruang selama 24 jam dan 48 jam kemudian dilakukan pengamatan terhadap diameter zona hambat yang terbentuk di sekitar kertas cakram (Kumar et al. 2014; Pelczar dan Chan. 1988). Pengukuran diameter daya hambat bakteri antagonis dilakukan dengan mengukur zona bening yang terbentuk di sekitar kertas cakram menggunakan jangka sorong digital (Bustamam 2006; Ernawati 2003).

\section{HASIL DAN PEMBAHASAN}

Hasil uji antagonis menunjukkan bahwa bakteri $P$. flourescens dengan kode isolat Sgu4 dan Sgu5 mampu menghambat pertumbuhan bakteri genus Xanthomonas sp (isolat SL3) yang ditunjukkan dengan adanya rata-rata diameter zona hambat. Berdasarkan Gambar 1 terjadi kenaikan diameter zona hambat dari jam 24 ke jam 48 pada semua perlakuan Pseudomonas flourescens spp., sedangkan pada perlakuan kontrol terjadi penurunan diameter zona hambat pada jam ke 48. Rata-rata diameter zona hambat pada perlakuan P1 (P. flourescens Sgu4 vs Xanthomonas sp. SL3) sebesar 6,95 mm (Tabel 1 dan Gambar 2b), sedangkan perlakuan P2( $P$. flourescens Sgu5 vs Xanthomonas sp. SL3) menghasilkan zona hambat mencapai $8,43 \mathrm{~mm}$ (Tabel 1 dan Gambar 2c).

Tabel1. Diameter zona hambat uji antagonis bakteri Pseudomonas flourescens spp. terhadap bakteri hawar daun (Genus Xanthomonas SL3) pada jam ke 24 dan jam ke 48

\begin{tabular}{cc} 
Perlakuan & $\begin{array}{c}\text { Rata-rata Diameter Zona Hambat } \\
(\mathrm{mm})\end{array}$ \\
\hline P0 (Kloramfenikol vs Xanthomonas SL 3) & 20,27 \\
P1 (P. flourescens Sgu4 vs Xanthomonas SL3) & 6,95 \\
P2 (P. flourescens Sgu5 vs Xanthomonas SL3) & 8,43 \\
\hline
\end{tabular}

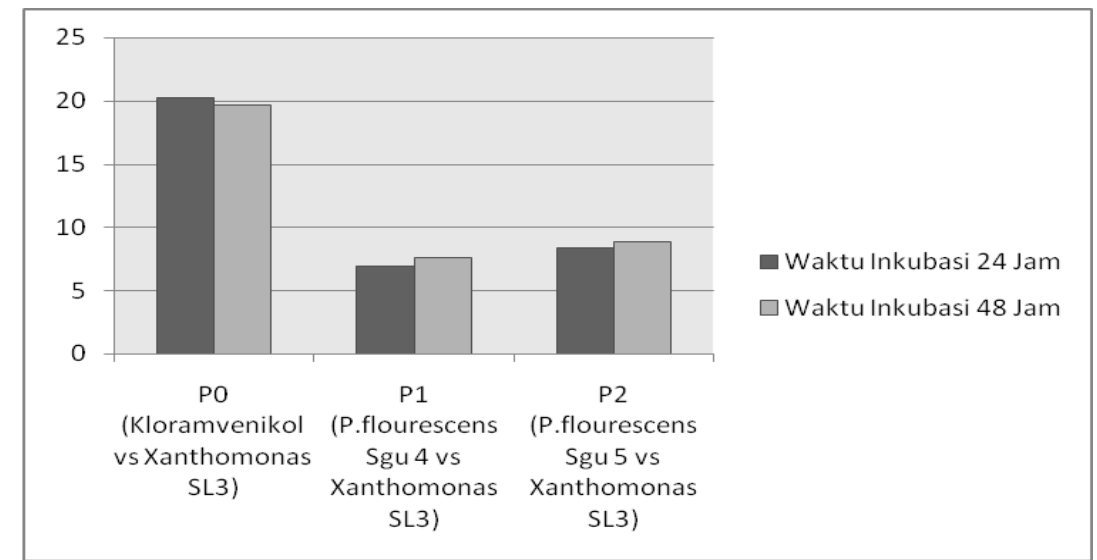

Gambar 1. Grafik uji antagoni Pseudomonas flourescens spp terhadap Xanthomonas SL3.

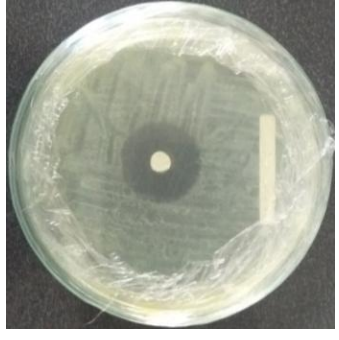

a

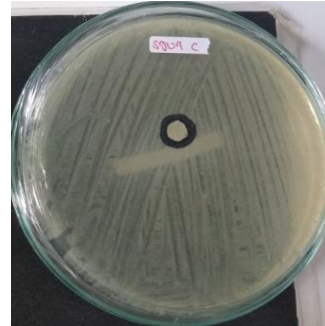

b

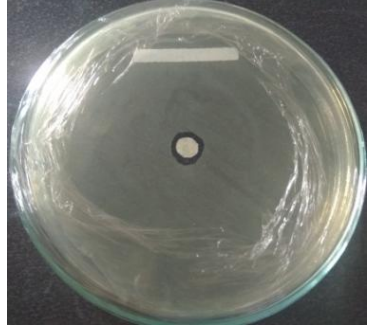

c

Gambar 2. Uji antagonis Pseudomonas flourescens spp. terhadap isolat bakteri hawar (a) kontrol, (b) P1(P. flourescens Sgu 4 vs Xanthomonas SL 3) (c) P2 (P. flourescens Sgu 5 vs Xanthomonas SL 3). 
Berdasarkan hasil penelitian, semua perlakuan mampu menghambat pertumbuhan bakteri patogen Xanthomonas SL 3. Rerata diameter zona hambat pada 48 jam lebih besar daripada diameter zona hambat pada 24 jam (Gambar 1). Adanya peningkatan ini menunjukkan bahwa ke dua bakteri antagonis yaitu P.flourescens Sgu 4 dan P.flourescnes Sgu 5 bersifat bakteriostatik. Menurut Wattimena (1991) apabila daerah hambatan yang terbentuk tidak lagi bening setelah masa inkubasi 48 jam atau daerah bening ditumbuhi kembali bakteri setelah masa inkubasi 48 jam berarti zat kimia yang bersifat antibakteri yang terkandung dalam suatu bahan bersifat bakteriostatik karena hanya mampu menghambat pertumbuhan bakteri tersebut. Hasil penelitian Sucipto (2009) juga menyatakan bahwa pertumbuhan bakteri ratarata meningkat dari jam ke 0 sampai mencapai puncak pada jam ke 48, setelah itu mengalami penurunan. Hasil uji antagonis pada penelitian ini memperlihatkan adanya hambatan pertumbuhan bakteri patogen Xanthomonas SL3 yaitu dengan terbentuknya zona hambat di sekitar kertas cakram (Gambar 2). Zona hambat terbentuk karena adanya suatu ekskresi yang dihasilkan bakteri $P$. flourescens dan meresap ke dalam media yang efeknya dapat menghambat patogen. Menurut hasil penelitian Zuraidah (2013) bakteri $P$. flourescens mampu menghasilkan zona hambat terhadap bakteri genus Xanthomonas dalam uji antagonis secara in vitro.

Penghambatan terbesar pada perlakuan dengan bakteri antagonis yaitu P2 ( $P$. flourescens Sgu 5) dengan zona hambat sebesar $8,43 \mathrm{~mm}$ sedangkan perlakuan P1 $(P$. flourescens Sgu 4) menghasilkan zona hambat sebesar 6,95 $\mathrm{mm}$ (Tabel 1). Perbedaan besarnya zona hambat antara perlakuan dua bakteri antagonis tersebut mengindikasikan adanya perbedaan kemampuan penghambatan antara $P$. flourescens Sgu 4 dan $P$. flourescens Sgu 5. Perbedaan kemampuan diduga karena adanya perbedaan senyawa yang dihasilkan oleh kedua strain bakteri $P$. flourescens. Kondisi ini sejalan dengan penelitian yang dilakukan oleh Mudji (2009) terhadap tujuh isolat $P$. flourescens yang berbeda terhadap bakteri Xanthomonas axonopodis pada kedelai menunjukkan bahwa dari ketujuh isolat $P$. flourescens tersebut memiliki daya hambat yang berbeda. Perbedaan daya hambat ini juga diduga karena adanya perbedaan kandungan enzim yang dimiliki oleh bakteri $P$. flourescens sehingga menyebabkan terjadinya perbedaan respon terhadap bakteri patogen. Perbedaan kadar enzim sesuai dengan penelitian yang dilakukan oleh Malik et al (2017); Kadhim dan Jarallah (2013) menyatakan bahwa isolat $P$. flourescens yang berbeda strain dan diisolasi dari rhizosfer yang berbeda memiliki kandungan enzim selulase yang berbeda pula.

Adanya zona hambat tersebut diduga bahwa bakteri $P$. flourescens menggunakan mekanisme antibiosis dalam menghambat pertumbuhan bakteri patogen. Menurut (Addy, 2007; Diarta et al. 2016) bakteri genus Pseudomonas menghasilkan senyawa antibiosis berupa pyoluteorin dan pyrrolnitrin yang bersifat toksik terhadap patogen. Senyawa tersebut merupakan salah satu senyawa antibiosis yang dapat merusak dinding sel, sehingga cairan yang ada di dalam dinding sel akan berkurang dan mengalami plasmolisis sehingga proses metabolisme akan terhambat. Hal ini sesuai dengan Agustono et al (2012) yang menyatakan bahwa bakteri anggota genus Pseudomonas dapat menghasilkan enzim tertentu yang dijadikan sebagai salah satu substansi antibakteri yang dapat menekan pertumbuhan bakteri patogen.

Berdasarkan penelitian Verschuere et al (2000) penghambatan pertumbuhan juga disebabkan karena adanya senyawa metabolit sekunder. Menurut Hassanein et al (2009), Pseudomonas sp. memiliki kemampuan untuk memproduksi metabolit sekunder seperti siderofor penghelat besi $(\mathrm{Fe})$, amonia, dan sianida. Lo (1998) dan Suhartiningsih et al (2013) menyatakan bahwa bakteri anggota spesies $P$. flourescens dapat menghasilkan siderofor yang dapat menekan pertumbuhan bakteri patogen. Couillerot et al (2009) cit Djaenudin (2016) juga menyatakan bahwa bakteri $P$. flourescens menekan populasi patogen dengan cara berkompetisi dalam penyerapan $\mathrm{Fe}^{2+}$, mengkolonisasi akar dan menghasilkan senyawa kimia berupa antibiotika.

Selain itu, hal ini juga diduga berkaitan dengan strain atau patotipe yang dimiliki oleh bakteri patogen Xanthomonas sehingga menyebabkan adanya perbedaan kemampuan penginfeksian terhadap inang. Menurut Addy (2005), mekanisme antagonistik agen pengendali hayati berbeda-beda tergantung pada genus, spesies dan strain bakteri antagonis maupun patogennya. Balai Besar Penelitian Tanaman Padi (2015) menyebutkan bahwa bakteri patogen Xanthomonas mampu membentuk strain atau 
patotipe yang lebih virulen yang menyebabkan terjadinya pergeseran dominasi patogen dari waktu ke waktu sehingga ketahanan inang menjadi lebih rentan. Penelitian Yuriah et al., 2013 menyebutkan bahwa tanaman padi dengan varietas IR 64 merupakan tanaman padi yang rentan oleh bakteri Xanthomonas tipe III yang dominan di Sulawesi, Kalimantan, Jawa dan Bali.

\section{KESIMPULAN}

Berdasarkan hasil penelitian mengenai uji daya hambat Pseudomonas flourescens spp. terhadap bakteri Xanthomonas sp (SL3) yang diisolasi dari daun padi IR 64 bergejala hawar di Kabupaten Kubu Raya dapat disimpulkan bahwa kedua strain isolat bakteri Pseudomonas flourescens ( $P$. flourescens Sgu 4 dan $P$. flourescens Sgu 5) bersifat bakteriostatik yaitu mampu menghambat pertumbuhan isolat bakteri patogen hawar daun genus Xanthomonas SL 3. Isolat bakteri Pseudomonas flourescens Sgu 5 memiliki kemampuan tertinggi dalam menghambat pertumbuhan isolat bakteri patogen hawar daun genus Xanthomonas SL 3 dengan diameter zona hambat sebesar $8,43 \mathrm{~mm}$.

\section{DAFTAR PUSTAKA}

Addy HS (2007) Pengaruh Sumber Mineral terhadap Penekanan Erwinia carotovora oleh Psudomonas pendarfluor secara In Vitro, Jurnal HPT Tropika, 7 (2).

Agustono, Suprapto H, \& Muhajir (2012) Strategi Bakteri Probiotik untuk Menekan Pertumbuhan Bakteri Patogen didalam Pencernaan Kerapu Chromileptes altivelis dengan Memproduksi Beberapa Bakteri Substansi: Jurnal Ilmiah Perikanan dan Kelautan, 4 (2):199-205.

Balai Besar Penelitian Tanaman Padi (2015) Hawar Daun bakteri (HDB) dan cara Pengendaliannya. Badan Penelitian dan Pengembangan Pertanian. Subang.

BPS (2016) Statistik Pertanian Tanaman Pangan (Padi dan Palawija) Kabupaten Kubu Raya. Badan Pusat Statistik. Kubu Raya.

Bustamam H (2006) Seleksi Mikroba Rizosfer Antagonis terhadap Bakteri Ralstonia solanacearum Penyebab Penyakit Layu Bakteri pada Tanaman Jahe di Lahan Tertindas, Jurnal Ilmu-Ilmu Pertanian 8 (1).

Couillerot O, combaret CP, Mellado JC \& Loccoz YM (2009) Pseudomonas flourescens and Close-Related Flourescens pseudomonads As Biocontrol Agents of
Soil-Borne Phytopathologents, lett, appl, microbiol.

Damanik S, Pinem MI \& Pengestiningsih Y (2013) Uji Efikasi Agens Hayati Terhadap Penyakit Hawar Daun Bakteri (Xanthomonas oryzae pv. oryzae) pada Beberapa Varietas Padi Sawah (Oryza Sativa), Jurnal Online Agroekoteknologi 1 (4): 2337- 6597.

Diarta IM, Javandira C \& Widnyana IK (2016) Antagonistik Bakteri Pseudomonas spp. dan Bacillus spp. terhadap Jamur Fusarium Oxysporum Penyebab Penyakit Layu Tanaman Tomat, Jurnal Bakti Saraswati, 5 (1): 2088-2149.

Djaenudin N (2016) Interaksi Bakteri Antagonis dengan Tanaman: Ketahanan Terinduksi Pada Tanaman Jagung, Jurnal Iptek Tanaman Pangan, 11 (2): 143-149.

Ernawati NML (2003) Potensi Mikroorganisme Tanah Antagonis untuk Menekan Pseudomonas solanacearum pada Tanaman Pisang Secara In Vitro di Pulau Lombok. Pengantar Falsafah Sains. Program Pasca Sarjana Institut Pertanian Bogor. Bogor.

Fitriah B, Irwan L \& Johanes P (2014) Eksplorasi terhadap Bakteri Endofit sebagai Agen Pengendali Hayati terhadap Penyakir Darah pada tanaman Pisang secara In Vitro, Jurnal Agrotekbis 2 (6): 579-578.

Hanudin B, Marwoto O \& Gunawan S (2009) Penapisan Beberapa Isolat P. fluorescens, Bacillus subtilis, dan Trichoderma harzianum yang Bersifat Antagonistik terhadap Ralstonia solanacearum pada Tanaman Kentang. Jurnal Agrikultura 20 (3): 198-203.

Hassanein WA, Awny NM, El-Mougith AA \& Salah El-Dien SH (2009) The Antagonistic Activities of Some Metabolites Produced by Pseudomonas Aeruginosa Sha8. Journal Appl, Sci, Res, 404-414.

Herawati A (2016) Isolasi dan Karakterisasi Penyebab Penyakit Hawar Daun Bakteri (Xanthomonas oryzae pv. oryzae L.) pada Tanaman Padi di Wilayah Sulawesi Selatan. Sekolah Tinggi Ilmu Pertanian YAPIM Maros. Sulawesi Selatan.

Kadhim AA \& Jarallah EM (2013) Screening of Cellulase Activity Produced from Pseudomonas fluorescens, Journal of Babylon University/Pure and Applied Sciences 3 (21): 549-754.

Kumar A, Shiv KV, Ashis \& Dhiraj KC (2014) Biochemical and Molecular Characterization 
of Antagonistic Bacteria Against Yellow Blotch of Oyster Mushroom, International Journal of Research in Engineering and Technology, 3 (4): 294-297.

Lo CT (1998) General Mechanisms of Action of Microbial Biocontrol Agents, Plant Pathology Bulletin, 7(4): 155-166.

Manimegalai R, Gopinath RS, Christy PM \& Divya D (2014) Isolation and Identification of Ace Togenic and Methanogenic Bacteria From Anoxic Black Sediments and Their Role in Biogas Production, International Journal of Plant, Animal and Environmental Sciences 4(3): 156-163.

Malik AF, Permana EI, Arifin MZ, Sukimin, Amalia M, Mulyono (2017) Karakterisasi dan Kajian Biokimia Pseudomonas fluorescens Lokal Spesifik Kalimantan Barat. Balai Proteksi Tanaman Perkebunan Provinsi Kalimantan Barat.

Mudji Rahayu (2009) Keefektifan Agen Hayati Pseudomonas flourescens dan Ekstrak Daun Sirih Terhadap Penyakit Bakteri Pustul Xanthomonas axonopodis pada Kedelai. Prosiding Seminar Hasil Penelitian Tanaman Aneka Kacang dan Umbi, Balai Penelitian Tanaman Kacang-Kacangan dan UmbiUmbian, Malang.

Nuria MC (2010) Antibacterial Activities Jangkang (Homalocladium platycladium (F.Muell) Bailey) Leaves, Jurnal MEDIAGRO 2 (2): 9-15.

Pelczar MJ \& Chan ECS (1988) Dasar-Dasar Mikrobiologi. Universitas Indonesia Press. Jakarta.

Sakinah AL \& Enny Z (2014) Resistensi Azotobacter terhadap $\mathrm{HgCl}_{2}$ yang Berpotensi Menghasilkan Enzim Merkuri Reduktase, Jurnal Sains dan Seni Pomits 3 (2): 84-86.

Sands DS (1990) Physiological CriteriaDeterminative Test. Dalam: Klement, Z,
Rudolph, K, and Sands, DC, Methods in Phytobacteriology. Akademisi Kado. Budapes.

Sucipto I (2009) Biogas Hasil Fermentasi Hidrolisat Bagas menggunakan Konsorsium Bakteri Termofilik Kotoran Sapi, Skripsi Program Studi Biokimia. Fakultas Matematika dan Ilmu Pengetahuan Alam Institut Pertanian Bogor. Bogor.

Verschuere L, Geert R, Patrick S, \& Willy V (2000) Probiotic Bacteria As Biological Control Agents in Aquaculture, Journal Microbiology, Mol, Biol, (64): 665-671.

Wattimena, Joke R (1991) Farmakodinami dan Terapi Antibiotik. Universitas Gadjah Mada Press.

Wibisono A, Majid A \& Mihardjo PA (2014) Efektivitas Beberapa Isolat Pseudomonas fluorescens untuk Mengendalikan Patogen Jamur Rhizoctonia solani pada Tanaman Kedelai, Jurnal Berkala Ilmiah Pertanian, 1 (1): 20.

Widodo TA, Maryudani YMS \& Azizah NN (2007) Sifat-Sifat Fenotipik Pseudomonas fluorescens, Agensia Pengendalian Hayati Penyakit Lincat pada Tembakau Temanggung, Jurnal Biodiversitas 8 (2): 147-151.

Yuriah S, Dwinita W, Utami \& Hanarida I (2013) Uji Ketahanan Galur-galur Harapan Padi terhadap Penyakit Hawar Daun Bakteri (Xanthomonas oryzae pv. oryzae) Ras III, IV, dan VIII. Balai Besar Penelitian dan Pengembangan Bioteknologi dan Sumber Daya Genetik Pertanian. Buletin Plasma Nutfah Bogor 19 (2).

Zuraidah (2013) Pengujian Beberapa Bakteri Penghambat Pertumbuhan Xanthomonas oryzae pv. oryzae pada Tanaman Padi, Jurnal Ilmiah Pendidikan Biologi, Biologi Edukasi 5 (1): 18-24. 